The International Journal of Indian Psychology

ISSN 2348-5396 (e) | ISSN: 2349-3429 (p)

Volume 5, Issue 1, DIP: 18.01.104/20170501

DOI: $10.25215 / 0501.104$

http://www.ijip.in | October-December, 2017

Original Research Paper

\title{
Efficacy of Gender and Age on Self-concept of School Level
}

\section{Student}

\author{
Jignesh $\operatorname{Jani}^{1 *}$
}

\section{ABSTRACT}

School students have to deal with a range of tasks, responsibilities, duties and academic assignments. In order to accomplish their individual, social and academic objectives successfully, students required possessing a set of competencies and a required level of intelligence and efficiency. Self concept of school students have become some of the most influential phenomenon in the management of educational and environmental stress. The present research attempt has been made (1) to study the effect of gender on self-concept of school level children (2) to study the effect of age on self-concept of school level students. It was hypothesized that gender and age have no impact on self concept of school students. To measure self-concept, self concept scale for children developed by Singh, H and Singh, S. published by Agra Psychological Research Cell was used. Statics like student ' $t$ ' and one way ANOVA tests were calculated Results: Self concept of girls were higher than the boys where as age has no impact on self concept of school level student. All the three age groups of school level student have more or less similar self concept.

Keywords: Adolescents, self-concept, Gender, Age Groups

Self-concept as a construct has had a long history within psychology and education because it provides a gauge to determine the effects of academic and social functioning on the emotional well-being of the school student. Self-concept is generally viewed as a valued educational outcome. Self-concept is typically defined as a person's general composite or collective view of themselves across multidimensional sets of domain specific perceptions, based on self-knowledge and evaluation of value or worth of one's own capabilities formed through experiences with and interpretations of the environment.

The literature on psychological assessment and evaluation is flooded with studies on selfconcept and its related constructs designated as self-esteem, self-efficacy, self-image and others on students (e.g., Banyard \& Grayson, 2000; Anastasi \& Urbina, 2007; Bowling, 2009). Intriguingly, there seems to be diverse opinions on the definition of self-concept. While some authors refer to it as a construct closely related to personality, that is, a relatively

\footnotetext{
${ }^{1}$ Research Scholar, P.G. Department of Psychology, Sardar Patel University, India *Responding Author

(C) 2017 Jani J; licensee IJIP. This is an Open Access Research distributed under the terms of the Creative Commons Attribution License (www.creativecommons.org/licenses/by/2.0), which permits unrestricted use, distribution, and reproduction in any Medium, provided the original work is properly cited.
} 
stable and distinctive patterns of behaviour that characterise an individual and his or her reactions to the environment (Kossowka, 2002; Kaplan \& Saccuzzo, 2005; Anastasi \& Urbina, 2007), some others view it as domain-specific evaluations of the self (Santrock, 2005; Whiston, 2005). However, in the context of present study, self-concept is defined as the way an individual thinks, feels, acts, values and evaluates himself or herself in relation to academic performance.

The importance of self-concept stems from its prominent contribution to personality development. Self-esteem has to do with social competence, since it influences how the person feels, how he or she thinks, learns, values himself or herself, relates to others, and ultimately, how he or she behaves (Clark, Clemes \& Bean, 2000; Clemes \& Bean, 1996).

Self-concept, as a component of individual personality development, has its own nature and peculiarity. Several authors (Shavelson et al.; 1976; quoted by Garma and Elexpuru, 1999) have attempted to specify the nature of the word self-concept. To this end, they look at it as a compendium of seven characteristics or fundamental aspects: Self-concept constitutes a psychological dimension; it is multidimensional; it has a hierarchical organization (a general self-concept and specific self-concepts); it is stable, but as we go lower on the hierarchy, selfconcept becomes more specific and more susceptible to change; the different facets of selfconcept become more differentiated among themselves with age and experience; self-concept includes both descriptive as well as evaluative aspects; self-concept can be differentiated from other constructs which it is related to, such as academic achievement.

Areepattamannil, S (2011), conducted a study to find out interactive effect of school type and learning styles of self-concept of students. This study pointed at the characteristic like learning style, self-concept etc., were related to performance in academics.

Dhanya (2011) in their comparative study of the self concept and level of aspiration of adolescent girls in ernakulam district of Kerala, India. Early adolescence is period that is characterized by heightened self consciousness and increased social comparision that compels early adolescents to evaluate their self identity. Figen (2012) reported that gender of adolescents living in orphanage, the number of their close friends, the influence of the views of their friends, the attitude of personnel towards the adolescents in their relationships with friends lead to difference in the self concept scores of adolescents according to gender and according to the place they live in cases of adolescents not living in orphanage. Ireson (2009) reported that student's intentions to learn in future were more strongly affected by selfconcept than by achievement. Musa (2012) concluded that there was significant there was a statistically significant effect of gender on academic effort and achievement, while also a statistically significant difference was shown in faculties on academic achievement. Neeraj (2011) reported that there was significant difference between the respondents from rural and urban area at self-concept. The adolescent girls from rural areas had high self concept. 


\section{Efficacy of Gender and Age on Self-concept of School Level Student}

\section{Significance of Problem:}

Self concept is important basis for detailed understanding about learning pattern of school students. Clarity on self concept helps in dealing with peer group adjustment. Self concept can be important tool in understanding emotional Intelligence and further studies could be helpful in dealing with IQ of school children. Self concept could be important in determining each group's perception on their own \& both group's positive and negative effect on self concept of student.

\section{Statement of problem:}

The present investigation attempts to "Efficacy of Gender and Age on Self-concept of School Level Student”.

\section{Objectives:}

$\checkmark \quad$ To examine and evaluate the efficacy of gender on self concept of school level children.

$\checkmark \quad$ To examine and evaluate the relationship among age groups of school level children on self concept.

$\checkmark \quad$ Make recommendations for the focus and development of future study in this field.

\section{Hypotheses}

The following research hypotheses were tested at.05 level of significance:

$\mathrm{HO}_{1}$ : There will be no significant mean difference between boys and girls with reference to their self concept

$\mathrm{HO}_{2}$ : There will be no significant mean difference among various age groups of student with reference to self concept.

\section{Research design:}

The present study is not possible experimentally because of nature of the investigation. The researcher adopted the quantitative descriptive research for gaining the objectives of present research. It is the survey quantitative research in which the event has already occurred and the effects of the variables were studied by qualitative analysis.

\section{Variables:}

Gender and age were taken as independent variable for the present study. Two categories of gender (boys and girls) and three categories of age (AG-1 9 to 11 Yrs., AG-2 12 to 14 Yrs \& AG-3 15 to 17 Yrs.) were selected for the present research work where as self concept of school student was taken as dependent variable.

\section{Sample:}

For the present research work researcher has selected initially 670 school students between age ranges of 9 to 17 years with the help of random sampling technique from Anand and Vadodara districts of Gujarat state. Further they were classified in boys (427) and girls (223) 
as per availability. Similarly total sample were divided into three age groups. i.e. Age Group1(166 ),Age Group-1(378) and Age Group-1(109).

\section{Tool:}

The tool for the present study was selected in a manner to achieve an optimum level of confidence by the researcher for the objectives of the study. Self concept scale for children developed by Singh, H and Singh, S. published by Agra Psychological Research Cell was used.

\section{Procedure:}

The investigator was familiar with the objectives of the study, methods, and ethical protocols. The researcher used a standardised protocol to communicate and interact, and build rapport with the school student. Then researcher had explained the importance of research work and collected the data after ensuring the confidentiality of them. Each subject was given a questionnaire of self concept. All were requested to read all statements one after the other and give their responses in the responses column by choosing appropriate responses for each statement, which they felt correct and appropriate.

\section{Scoring:}

In the present study, scoring of the obtained data was done with help of respective manuals available for the test. The data have been arranged in the respective table according to the statistical test applied.

\section{Statistical Analysis:}

In the present study to find out the significant difference between gender student ' $t$ ' test, Mean and SD were calculated where as to find out significant difference among age groups one way ANOVA test were administered with the help of SPSS software.

\section{RESULT \& DISCUSSION}

Table:-1 Showing Mean, SD \& ' $t$ ' value between boys and girls on self concept of school level student.

\begin{tabular}{|c|c|c|c|c|c|}
\hline Measures & Groups & $\mathbf{N}$ & Mean & SD & \multirow{2}{*}{ 't' Value } \\
\hline \multirow{2}{*}{ Self Concept } & Boys & 427 & 81.63 & 17.96 & \multirow{2}{*}{$2.94 p<.01$} \\
\cline { 2 - 5 } & Girls & 223 & 85.76 & 14.87 & \\
\hline
\end{tabular}

A perusal of table 1 shows that the two groups under study i.e. boys and girls differ significantly on scores of self concept. The significant mean difference is to be reported for the boys and girls (' $\mathrm{t}$ '=2.94, $p<.01)$. Girls have scored higher mean $(\mathrm{M}=85.76, \mathrm{SD}=4.87)$ than boys $(\mathrm{M}=81.63, \mathrm{SD}=17.96)$. Therefore, $\mathbf{H O}_{\mathbf{1}}$ is declined, it may be said that gender has influence on self concept of school student. In other words, girls have greater self concept as compared to boys. 
Table:-2 Showing Mean, SD \& F value among various age groups of school level student on self concept

\begin{tabular}{|c|c|c|c|c|c|}
\hline Measures & Groups & N & Mean & SD & F \\
\hline \multirow{3}{*}{ Self Concept } & 9 to $11 \mathrm{Y}$ & 166 & 82.25 & 17.34 & \multirow{3}{*}{$0.63 p>.05$} \\
\cline { 2 - 5 } & 12 to $14 \mathrm{Y}$ & 378 & 82.54 & 17.51 & \\
\cline { 2 - 5 } & 15 to $17 \mathrm{Y}$ & 109 & 84.51 & 18.56 & \\
\hline
\end{tabular}

Table no.2 indicates $\mathrm{F}$ value and mean score for age groups of school students in which $\mathrm{F}$ ratio is reported insignificant $\mathrm{F}=0.63, p<.05$. Mean score obtained by Age Group-I is 82.25 $(\mathrm{SD}=17.34)$, for Age Group-II is $82.54(\mathrm{SD}=17.51)$ and for Age Group-III is 84.51 (SD = 18.56) respectively. On the basis of insignificant mean difference it can be said that all three groups have by and large similar on their self concept. Thus, $\mathrm{HO}_{2}$ is strongly accepted.

\section{CONCLUSION}

Self-concept and self-esteem are among the most widely discussed but misunderstood constructs in education. As per the general principle in education, a student needs good selfconcept in order to be successful academic life. To achieve this success, schools can impact their student academic self-concept by developing an organized, orderly and supportive environment. In a rapid changing global, the cultivation of an all-round personality, sensitive to problems in environment, is important, vital and necessary for school level children.

\section{IMPLICATIONS}

Self concept has many facets and there are varying level of each faces. Now, when real time classroom situation arises, where teacher may not be interested in self concept as theoretical construct, teachers would mostly be effective in dealing with student by confining student to facet of self concept which specific to the problem at hand. For e.g.: a girl who had a great deal of trouble in reading, this girl was whipped when asked her to read a book, however when girl was let off school group singing program she evidenced self satisfaction. So it was believed that girl could be helped in approaching reading with measure of confidence more akin to that with which the girl approached group singing competition, success would be much more likely.

So there is continuous need to refine and redefine role of Student's self-image in their behavior from Researcher and Teacher's point of view.

\section{RECOMMENDATION OF FUTURE RESEARCH}

Nowadays, there are number of new concept schools emerging in India and around the globe where researcher can test self concept of student of this different concept schools which can help to decide in acceptance and approval of better teaching module. Every School must have trained counselor or counseling services so that self concept can be evaluated from time to time to make understanding of self concept for better Peer group adjustment, Parent child relationship as well as better Human relations at large. 


\section{Efficacy of Gender and Age on Self-concept of School Level Student}

\section{Acknowledgments}

The author appreciates all those who participated in the study and helped to facilitate the research process.

Conflict of Interests: The author declared no conflict of interests.

\section{REFERENCES}

Areepattamannil, S.(2011): Academic Self-concept, Academic motivation, Academic Engagement and Academic achievement, A mixed method study of Indian Adolescents in Canada and India, Ph.D. Dissertation, Queen's University: Ontario.

Beane, A. \& Lipka, R.P.(1980). Self concept and self-esteem: A Construct differentiation. Child Study Journal, 10,1-6.

Brookover, W.B. (1965). Self concept of Ability and school Achievement II: Improving academic achievement through student's self concept enhancement. U.S. office of Education, Research and Publications, Michigan State University.

Calhoun,G., Jr., \& Morse, W.C.(1977). Self-concept and self-esteem: Another perspective. Psychology in the schools, 14,318-322.

Clark, A., Clemes, H. \& Bean, R. (2000). Cómo desarrollar la autoestima en adolescentes. [How to develop self-esteem in adolescents]. Madrid: Editorial Debate

Clemes, H., \& Bean, R. (1996). Cómo desarrollar la autoestima en los niños. [How to develop self-esteem in children].Madrid: Editorial Debate.

Dhanya N. and Rekha R.K.(2011) Comparitive study of the Self concept and level of aspiration of adolescent girls in ernakulam district of kerala, India. International Journal of Current Research Vol.3, Issue, 12, pp.011-016, December, 2011.

Figen, Gursoy et al. (2012) Self-concept levels of adolescents in the age group of 13-18 who live in orphanage and those who do not live in orphanage and those who do not live in orphanage. International Journal of Social Sciences and Education ISSN: 2223-4934 Volume:2 Issue: 1 January 2012.

Ireson, Judith and Hallam, Susan (2009) Academic Self-Concepts in Adolescence: Relations with Achievement and Ability Grouping in Schools. Learning and Instructions, v19 n3 p201-213.

Jamaludin Ahmad, Mazila Ghazali Aminuddin Hassan (2011) Relationship between self concept and response towards student's academic achievement among student's leaders in University Putra Malaysia. International Journal of Instruction July 2011. Vol.4, No.2

Kamaljit Kaur (2012) Influence of slef concept on academic achievement of adolescents. International Indexed and Referred research Journal, ISSN-2250-2599; Vol.1, ISSUE1 Oct.,2012.

Musa Matovu (2012) academic self-concept and academic achievement among university students. International Online Journal of Educational Sciences, 2012, 4(1).107-116.

Neeraj 92011) Self-concept of the Adolescent Girls from Rural and Urban Areas. Vol.1, Issue.XI/Dec; 11pp.1-4 Indian Streams Research Journal ISSN:-2230-7850. 


\section{Efficacy of Gender and Age on Self-concept of School Level Student}

Thomas, S. (1966). An Experiment to enhance self-concept of ability and raise school achievement among low-achieving ninth grade students. Dissertation Abstracts International, 26(4), 870.

West, C.K., Fish, J.A., \& Stevens, R.J.(1980). General Self Concept, Self Concept of academic ability and school achievement: Implications for “causes” of self concept. Australian Journal of Education 24,194-213.

Wylie, R.C. (1979). The Self-concept: Theory and research on selected topics: Vol.2( rev.ed.).Lincoln: University of Nebraska Press.

How to cite this article: Jani J (2017). Efficacy of Gender and Age on Self-concept of School Level Student. International Journal of Indian Psychology, Vol. 5, (1), DIP: 18.01.104/20170501, DOI: 10.25215/0501.104 